Inetta Nowosad

https://doi.org/10.26881/pwe.2020.48.06

ORCID: 0000-0002-3739-7844

Uniwersytet Zielonogórski

i.nowosad@ipp.uz.zgora.pl

\title{
Przedszkola w debacie polityczno-oświatowej Niemiec. W stronę edukacji, opieki i wychowania
}

\begin{abstract}
Summary
Preschools in the political-pedagogical debate in Germany.

Towards education, care, and upbringing

Contemporary pre-school institutions in Germany have ceased to be perceived solely as providers of care. Significant importance has been assigned to education and upbringing as equivalent categories. The change in approach is not only apparent in their organisation and functioning, but also in state policies, which clearly emphasise the importance of early childhood. The aim of the article is to analyse the political-pedagogical debate that has been in progress since 2005, as well as to scrutinise the adopted arguments and their consequences in the form of the ever changing early school education and care in Germany. The analysis of conditions that have contributed to bestowing preschools with such significance, not only in the process of early childhood development, but also in the process of more broadly understood social development, has also been recognised as equally important, as a result of which preschool institutions have gained importance in the area of political investment that is equal to that granted to schools. The analysis of educational reports and formal-legal guidelines on both federal and state levels is meant to illustrate the range of the introduced changes and the specifics of the German reform, which is perceived as an interlinked network and as cooperation for the sake of children and their families.
\end{abstract}

Keywords: early childhood education and care, preschools, educational policy, Germany

Słowa kluczowe: wczesna opieka i edukacja, przedszkola, polityka edukacyjna, Niemcy

\section{Wprowadzenie}

Zwrócenie uwagi na przedszkola w Niemczech trudno nazwać przypadkowym. Niemcy, jak mało który kraj, mogą się poszczycić w tej dziedzinie bogatym i trwałym dorobkiem. To w Bad Blankenburgu Friedrich Wilhelm Fröbel w 1840 r. założył pierwsze przedszkole, które nazwał „ogródkiem dziecięcym” (Kindergarten). Jednak w żadnym innym kraju siła nowych koncepcji nie była w tak ostro konfrontowana z rzeczywistością społeczno-kulturową; śmiałe idee i pomysły, odważnie wdrażane rozwiązania oparte na rezultatach badań spotykały się z oporem lub sprzeciwem ze strony polityków. Zamysł Fröbla dotyczący zakładania „ogródków dziecięcych” nie był akceptowany przez ówczesne władze, 
a freblowskie przedszkola zostały zamknięte na kilka lat. Opór władz nie przeszkodził jednak w powstaniu swoistego ruchu społecznego na rzecz wychowania przedszkolnego, wspieranego bardziej przez pedagogów i działaczy oświatowych niż przez państwo.

Po postulaty freblowskie sięgnięto po II wojnie światowej. Przedszkola w państwie niemieckim w tych dwóch różnych okresach przeszły jednak przez dwie odmienne drogi rozwoju zarówno w zakresie form organizacyjnych, jak i koncepcji pedagogicznych. Po zjednoczeniu Niemiec można było oczekiwać intensywnego rozwoju placówek szanujących dzieciństwo i respektujących wolność dzieci, ale niestety tak się nie stało. Poważne zainteresowanie polityków oświatowych instytucjami przedszkolnymi nastąpiło dopiero po opublikowaniu w Niemczech rezultatów badań PISA. Punktem zwrotnym okazał się rok 2005, w którym Niemieckie Towarzystwo Nauki o Wychowaniu (Deutsche Gesellschaft für Erziehungswissenschaft) zorganizowało sympozjum na temat Akademisierung der Erzieherinnenausbildung? Zwrócono na nim uwagę na konieczność rozbudowy systemu uniwersyteckiego kształcenia wychowawców przedszkoli i na potrzebę rozwoju placówek wczesnej edukacji (Frühpädagogik) dziecka (DGfE 2005).

Od 2005 r. przedszkola znajdują się w centrum publicznej debaty, co przyczyniło się do zmiany przyjmowanych terminów odnoszących się do instytucji wczesnej edukacji i realizowanych przez nie funkcji. Terminy: Frühkindliche Bildung, Betreuungund Erziehung (FBBE), Bildungund Erziehung in Kindertagesberatuung; Bildungund Betreuung; frühkindliche Bildung, thumaczone są jako: wczesna edukacja, opieka i wychowanie; kształcenie i wychowanie w placówkach opiekuńczych dla dzieci czy też edukacja wczesnego dzieciństwa. Określenia te są nadawane instytucjom obejmującym swoją działalnością dzieci od ich urodzenia do czasu podjęcia realizacji obowiązku szkolnego. Terminy te odnoszą się zarówno do instytucji funkcjonujących powszechnie jako żłobki (dla dzieci od urodzenia do 3. r.ż.) lub przedszkola (dla dzieci 3-6-letnich), jak również do placówek opieki dziennej czy centrów edukacyjnych dla dzieci. Zakres, treść i kontekst działalności tych placówek były i nadal są dyskutowane przez pedagogów i działaczy oświatowych.

Co ciekawe, instytucjami przedszkolnymi, poza ekspertami z dziedziny pedagogiki, zaczęli się również interesować politycy i działacze społeczni. W rezultacie nastąpił wzrost znaczenia przedszkola dla społeczeństwa i jego roli w społeczeństwie. Główną kwestią poddawaną dyskusji jest jakość pracy placówek. Podkreśla się również konieczność zwiększenia liczby miejsc w przedszkolach. Efektem dyskusji podejmowanej w kręgach polityków oświatowych było zatwierdzenie do realizacji wielu projektów i programów finansowanych z budżetu państwa, które mają poprawić organizację i funkcjonowanie zarówno przedszkoli, jak i pozostałych placówek wczesnej edukacji dzieci.

Placówki przedszkolne w Niemczech przestały być rozpatrywane wyłącznie przez pryzmat wypełnianych przez nie funkcji opiekuńczych. Jednakową wagę zaczyna się przywiązywać do kwestii związanych z edukacją, wychowaniem i opieką. W 1999 r. Niemieckie Federalne Ministerstwo ds. Rodzin, Osób Starszych, Kobiet i Młodzieży (Bundesministerium für Familie, Senioren, Frauenund Jugend) zainicjowało w całych Niemczech działania na rzecz jakości w systemie placówek opieki dziennej (NQI). Czas, jaki upłynął 
od tej pierwszej inicjatywy, obfitował w działania zmieniające podejście do polityki edukacyjnej dotyczącej małych dzieci. W debatach, często burzliwych, zwrócono uwagę na zapomniane przez polityków instytucje przedszkolne. Uznano je za obszar opłacalnych inwestycji politycznych równie ważny jak szkoły.

Celem artykułu jest ukazanie istotnych dla organizacji i funkcjonowania niemieckich przedszkoli argumentów przywoływanych w debatach oświatowych oraz przedstawienie efektów tych debat. Równie ważne jest dokonanie analizy uwarunkowań, które przyczyniły się do nadania przedszkolom istotnego znaczenia nie tylko dla rozwoju dziecka, lecz także dla społeczeństwa. W niemieckiej prasie nie dziwią już artykuły o tytułach wskazujących, że: „walkę z ubóstwem dzieci wygra się w przedszkolach i szkołach" (Stasik 2019).

\section{Kontekst debaty wokól wczesnego dzieciństwa}

W Niemczech, podobnie jak w pozostałych krajach europejskich, na przestrzeni lat 19902010 zaszły znaczące zmiany społeczne i gospodarcze, do których można zaliczyć:

- spadek liczby urodzeń dzieci - po 1990 r. liczba ta jest w Niemczech jedną z najniższych w Europie;

- imigracja - na to zjawisko ma wpływ wysokie zapotrzebowanie na pracowników i ich sukcesywny napływ. Obecnie napływ pracowników gwałtownie rośnie, co wiąże się z coraz większą liczbą imigrantów z krajów objętych wojną i ubiegających się o azyl;

- rosnący stopień bezrobocia przy jednoczesnym zapotrzebowaniu na pracowników fizycznych - zjawisko to od lat 80 . XX w. stanowi poważny problem społeczny.

Splot tych niekorzystnych przeobrażeń społecznych w Niemczech i jednoczesny rozwój neuronauki (Koller 2012) zmieniał dotychczasowe podejście do systemu instytucji przedszkolnych (EKM 2009). Czynnikiem wywołującym debaty polityczne na temat opieki na dzieckiem są międzynarodowe analizy i rekomendacje (OECD 2001, 2006, 2013; UNICEF 2008; Eurydice-Netz 2009; EKFF 2009, 2008). Podobną tendencję można zauważyć w innych krajach Europy, w których wczesna opieka i edukacja jako zintegrowana strategia zyskała uznanie społeczno-polityczne (Komisja Europejska//EACEA/ Eurydice 2014; Eurydice Report 2019). W latach 90. silnym bodźcem rozwoju instytucji przedszkolnych okazał się rosnący wskaźnik zatrudnienia kobiet. Kwestia pogodzenia pracy z życiem rodzinnym powróciła po prawie 200 latach i stała się jednym z wiodących tematów w agendzie europejskiej. Rozwój usług opiekuńczych powiązano z działaniami promującymi równość kobiet i mężczyzn na rynku pracy. To tło polityki gospodarczej obejmuje również cele barcelońskie przyjęte na poziomie europejskim. Cele te stanowią część europejskiej strategii na rzecz wzrostu gospodarczego i zatrudnienia w całej Unii Europejskiej. Na ich podstawie wiele krajów podjęło działania rozwijające i doskonalące usługi w zakresie wczesnej edukacji opieki nad dzieckiem. 
Cele barcelońskie określone przez Radę Europejską w 2002 r. wyznaczają poziomy odniesienia w zakresie opracowywania ofert: „Państwa członkowskie powinny usunąć bariery w uczestnictwie kobiet w życiu zawodowym i dążyć do zaspokojenia popytu na placówki opieki nad dziećmi i zgodnie z normami krajowymi. Zapewnienie opieki powinno wystąpić na poziomie co najmniej $90 \%$ dzieci w wieku od trzech lat do obowiązkowego wieku szkolnego oraz co najmniej 33\% dzieci w wieku poniżej trzech lat" (Schlussfolgerungen des Vorsitzes Europäischer Rat 2002: 13). Wskaźniki te nadal służą ukazaniu obrazu ekspansji instytucji przedszkolnych i żłobkowych w poszczególnych krajach.

W 2014 r. grupa ekspertów z 27 krajów europejskich na zlecenie Rady Europy opracowała „Wytyczne dotyczące jakości” w zakresie wczesnej edukacji i opieki nad dzieckiem (,, Qualitäts Leitrahmen” für frühkindliche Bildungund Betreuung), które stymulowały reformy w wielu krajach europejskich lub zapewniały wsparcie pod wprowadzane reformy (Lazzari 2017). Sformułowano w nich konkretne cele i środki dotyczące: dostępu do placówek, umiejętności, programów edukacyjnych (programów nauczania), oceny i monitorowania oraz zarządzania i finansowania wczesnej edukacji, które mogą pomóc w kształtowaniu polityki na szczeblu lokalnym, regionalnym i krajowym (EU-Arbeitsgruppe für Frühkindliche... 2014).

Od końca lat 90. XX w. Organizacja Współpracy Gospodarczej i Rozwoju (OECD) również kształtowała międzynarodową debatę ogniskującą się na okresie przed podjęciem przez dziecko realizacji obowiązku szkolnego. Opublikowany Zestaw narzędzi jakości łączył strategie reform, doświadczenia i przykłady dobrych praktyk w zakresie rozwoju jakości i zapewnienia wczesnej edukacji, opieki i wychowania dzieci (OECD 2013). Choć sama organizacja jest dość kontrowersyjna na niemieckiej scenie oświatowej ze względu na liberalną orientację ekonomiczną, podejmowane przez nią inicjatywy mobilizujące politykę edukacyjną, w tym badania PISA, zmieniły niemiecką debatę na temat edukacji w okresie wczesnego dzieciństwa, a w niektórych obszarach nawet wyraźnie ją przyspieszyły.

\section{Wczesne wsparcie dziecka jako zadanie państwa i priorytet w polityce edukacyjnej}

Powstające w Niemczech od lat 30. XIX w. placówki dla małych dzieci różnie nazywano, co uzasadniano zwykle odmiennością ich koncepcji lub charakterystycznymi uwarunkowaniami terytorialnymi, na których placówki się znajdowały. Julius Fölsing zwracał uwagę na to, że kłótnia o jedną i tożsamą nazwę placówek jest w gruncie rzeczy mało istotna. $\mathrm{O}$ wiele ważniejsze bowiem jest to, jak powinno się $\mathrm{w}$ nich zajmować dziećmi, by osiągnąć założone cele (Kopp, za: Erning 1987: 21). Głównym zadaniem było uzupełnienie wychowania w rodzinie, placówki miały bowiem umożliwić matkom wypełnienie innych ciążących na nich obowiązków. Poza placówkami z możliwością przyjmowania dzieci na kilka godzin w ciągu dnia istniały również takie, które funkcjonowały w stylu ochronek - prowadziły całodzienną opiekę. Mimo istniejącego już na tym wczesnym etapie istotnego zróżnicowania placówek można uznać, że zakładane w Europie od XVIII w. 
placówki i te powstające nieco później w krajach niemieckojęzycznych zasadniczo realizowały zapotrzebowanie społeczne na opiekę, elementarne nauczanie, realizację celów pedagogicznych czy też przygotowania do podjęcia pracy. Bogactwo istniejących form placówek dla dzieci było ściśle powiązane z poglądami lub interesami inicjatorów, choć oczywiście było zdeterminowane warunkami politycznymi, ekonomicznymi oraz społecznymi. W czasie powstawania placówek opiekuńczo-wychowawczych nie rozpoznano wyraźnego oddzielenia dominujących funkcji (tab. 1) jako aspektów wsparcia rodziny i działań szkolnych, nastąpiło to w połowie XIX w. Prace pedagogiczne Friedricha Fröbla doprowadziły do rozdzielenia zadań instytucji związanych z rodziną i szkołą. W dalszym rozwoju historycznym przedszkola mogły się wyodrębnić jako niezależne instytucje edukacyjne dla małych dzieci.

Tabela 1. Wiodąca funkcja i misja placówek dla małego dziecka w krajach niemieckojęzycznych

\begin{tabular}{|l|l|l|}
\hline \multicolumn{1}{|c|}{ Wiodąca funkcja } & \multicolumn{1}{|c|}{ Misja } & \multicolumn{1}{c|}{ Przedstawiciele } \\
\hline opieka & $\begin{array}{l}\text { - wspieranie rodzin w nadzwyczajnych } \\
\text { sytuacjach } \\
-\begin{array}{l}\text { ochrona dzieci przed zaniedbaniem } \\
\text { fizycznym i moralnym }\end{array}\end{array}$ & $\begin{array}{l}\text { Pauline von Lippe-Detmold } \\
\text { Josef Wertheimer }\end{array}$ \\
\hline \multirow{3}{*}{ edukacja } & $\begin{array}{l}\text { zdobycie podstawowych umiejętności } \\
\text { czytania, pisania i liczenia } \\
- \text { edukacja moralna }\end{array}$ & $\begin{array}{l}\text { Johann Friedrich Oberlin } \\
\text { Theresia Brunsvik } \\
\text { Julius Fölsing } \\
\text { Theodor Fliedner }\end{array}$ \\
\hline wychowanie & $\begin{array}{l}\text { zaangażowanie eklezjalne } \\
\text { orientacja na potrzeby dziecka }\end{array}$ & Johpieranie dziecka w rozwoju \\
& $\begin{array}{l}\text { zabawa jako podstawowa forma } \\
\text { aktywności dziecka }\end{array}$ & \\
\hline
\end{tabular}

Źródło: opracowanie własne.

Przełom XX i XXI w. w Niemczech, a w zasadzie początek nowego stulecia, wydaje się odzwierciedlać równie silny rezonans debaty polityczno-oświatowej jak tej dziewiętnastowiecznej. Po raz kolejny pojawiły się w Niemczech impulsy pochodzące ze sfery gospodarki i nauki oraz dochodzące od społeczeństwa, które doprowadziły do przewartościowania dotychczasowych ustaleń formalno-prawnych i zwróciły uwagę na potrzebę rozpoznania i zrozumienia aktualnych koncepcji pedagogicznych oraz całościowego podejścia do systemu instytucji wczesnej edukacji podbudowanego doświadczeniem zbieranym w tym kraju od ponad dwustu lat.

Po 2000 r. w Niemczech zmieniło się podejście do misji przedszkola. Przedszkola, a nawet szerzej - wszystkie placówki obejmujące wsparciem (opieką i edukacją) dzieci do lat 6 są rozpatrywane przez pryzmat edukacji, opieki i wychowania (Reyer 2006). W debatach polityczno-oświatowych są one nazywane w skrócie instytucjami wczesnej edukacji (Frühkindliche Bildung) od pełnej nazwy eksponującej wczesną edukację, opiekę i wychowanie (Frühkindliche Bildung, Betreuung und Erziehung - FBBE) (Pabst, Schoyerer 2015). 
Można zatem sądzić, że instytucje przedszkolne uzyskały swoją edukacyjno-polityczną lokalizację w systemie edukacji. Jednak od 9 lipca 1922 r., gdy wprowadzono ustawę regulującą kwestie opieki nad młodzieżą (Reichsjugendwohlfahrtsgesetz - RJWG) i określono przepisy dotyczące instytucji przedszkolnych, ich misja wspierania rodziny w funkcji opiekuńczej w zasadzie nie uległa zmianie. Opieka nad małymi dziećmi była bowiem częścią usług opieki nad dziećmi i młodzieżą, a zatem należała do podobszaru opieki społecznej. Również po zjednoczeniu Niemiec i wprowadzonych od 1990 r. zmianach przepisów zostały one zastąpione ustawą o opiece nad dziećmi i młodzieżą, ogniskującą kwestie dotyczące funkcjonowania placówek przedszkolnych w obszarze opieki (Harsch 2008: 109-115).

Punktem zwrotnym była rezolucja przyjęta w 2002 r. przez Konferencję Ministrów ds. Młodzieży, wprowadzająca wytyczne dotyczące planów kształcenia, które wyznaczyły ramowe cele edukacji przedszkolnej jako podstawę programową dla organizacji pracy instytucji przedszkolnych. Wprowadzone zmiany można odczytać jako bezpośrednią reakcję polityczną na niezadowalające wyniki badań PISA opublikowane w 2001 r. i efekt podjętej, praktycznie z dnia na dzień, burzliwej dyskusji na temat stanu i jakości niemieckiej edukacji. Przedszkola, w przeciwieństwie do szkół, nie dysponowały żadnymi wytycznymi programowymi. Sytuacja ta we wszystkich krajach związkowych zmieniła się w latach 2002-2006, kiedy to opublikowano zalecane plany kształcenia. Dokonano tego w celu częściowego ujednolicenia koncepcji, na których opierają swoją działalność placówki przedszkolne i ośrodki opieki dziennej. Punktem wyjścia opracowania wytycznych był przegląd rozwiązań przyjmowanych w innych krajach europejskich. Na przykład w Finlandii i Norwegii podobne wytyczne istnieją od 1966 r., w Szwecji od 1998 r., Szkocji od 1999 r., a od 2000 r. w Anglii.

Wprowadzenie ramowych planów kształcenia przyczyniło się do wyznaczenia ogólnych zadań edukacyjnych w obszarze placówek zajmujących się małymi dziećmi. Tym samym podkreślono szczególne znaczenie misji edukacyjnej placówek przedszkolnych. Wyeksponowano ich odpowiedzialność za pomyślne dorastanie dzieci, która miała się opierać na połączeniu edukacji, opieki i wychowania. Edukacji przypisano fundamentalne znaczenie, także w sensie promowania samokształcenia (Jugendministerkonferenz 2002). Konferencja Ministrów ds. Młodzieży wezwała tym samym wszystkie organy prowadzące instytucje przedszkolne, zarówno publiczne, jak i prywatne, oraz kraje związkowe do zintensyfikowania mandatu edukacyjnego w zakresie opieki dziennej nad dziećmi i do konsekwentnego wdrażania oraz inicjowania nowych sposobów projektowania procesów edukacyjnych (Jugendministerkonferenz 2002). W 2004 r. przedstawiciele Ministerstwa ds. Młodzieży oraz Ministerstwa Edukacji doszli do porozumienia i doprecyzowali wspólną strategię dotyczącą wczesnej edukacji. Kraje związkowe zostały poproszone o opracowanie i opublikowanie podstawowych planów kształcenia, na podstawie których instytucje przedszkolne powinny tworzyć własne koncepcje specyficzne dla swoich placówek. Zapoczątkowany w ten sposób proces jest całkowicie nowy, ponieważ w Republice Federalnej, w przeciwieństwie do NRD, działania w tym zakresie nie były podejmowane. Obecne plany kształcenia (plany pracy pedagogicznej), 
inaczej niż w NRD, mają charakter rekomendacyjny i służą raczej jako przewodnik po pedagogicznym projekcie wczesnej edukacji, pozostawiając przedszkolom dużą swobodę. To gwarantuje, że wszystkie koncepcje wczesnego dzieciństwa, takie jak pedagogika Montessori, Fröbla, Steinera czy też podejście sytuacyjne lub pedagogika Reggio Emilia, można odnaleźć w bogatym krajobrazie przedszkoli w Niemczech.

\section{W stronę wczesnodziecięcej edukacji, opieki i wychowania (FBBE)}

Określenie Frühkindliche Bildung, Betreuungund Erziehung (FBBE), które można przethumaczyć jako wczesną edukację, opiekę i wychowanie dziecka, eksponuje trzy kluczowe terminy jako równoważne, z których „edukacja” (Bildung) odnosi się do indywidualnych procesów poznawczych dziecka. Obejmuje nabywanie przez dziecko nowych umiejętności i rozwój procesów poznawczych w celu stworzenia obrazu świata. W tym znaczeniu edukacja jest rozumiana jako wkład dziecka we własny rozwój. Natomiast „wychowanie” (Erziehung) i ,opieka” (Betreuung) oznaczają wkład dorosłych w edukację i rozwój dzieci. Wychowanie stanowi projekt inspirującego środowiska edukacyjnego, w którym dorośli zapewniają dzieciom wszechstronne doświadczenia edukacyjne i będą stanowić dla dziecka przykład. Opieka oznacza wsparcie społeczne w zakresie zaspokajania podstawowych potrzeb (także uczuć, emocji) i pielęgnacji dzieci, ochronę przed zagrożeniami, a także nawiązywanie ważnych relacji osobistych (rys. 1).

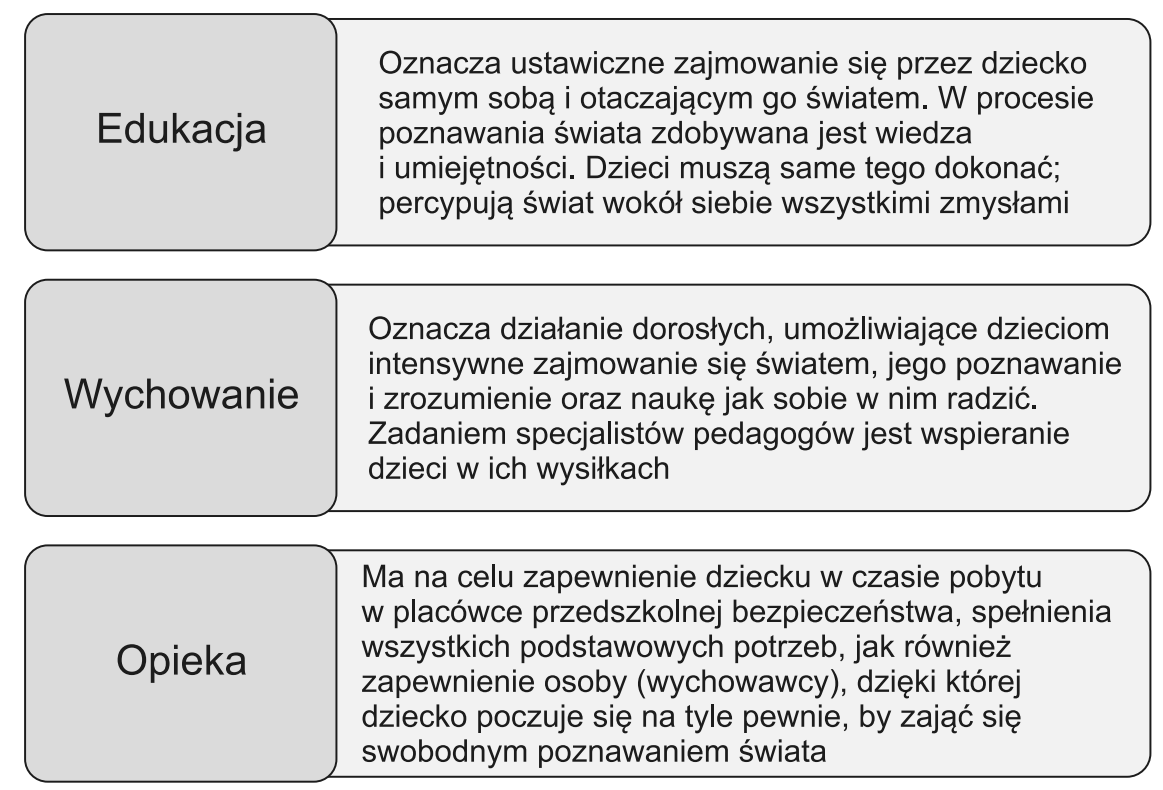

Rysunek 1. Edukacja, wychowanie i opieka w misji przedszkoli

Źródło: opracowanie własne na podstawie: Life Experience (2019). 
Przyjmuje się, że skuteczne procesy edukacji, wychowania i opieki we wczesnym dzieciństwie zaczynają się od dnia narodzin i trwają do momentu wejścia dziecka do szkoły podstawowej. Na tym etapie oferty i środki oddziaływania są połączone w spójną sieć oddziaływań i obejmują wszystkie środowiska życia dzieci, angażując w to rodziców. $\mathrm{Z}$ tego względu jakość edukacyjna stale się zmienia. Rozwój debaty oświatowej w kierunku kompleksowej, spójnej wczesnej edukacji, opieki i wychowania uświadamia istnienie problemu oraz potrzebę zmiany podejścia. Podejście to, mimo że od czasów powołania w Niemczech pierwszych przedszkoli przeszło znaczną ewolucję, jednak nie rozwiązało wszystkich kwestii wymagających natychmiastowej uwagi. Przyczyn nowego podejścia można się doszukiwać w wielu obszarach, począwszy od zmian społecznych po wyniki badań naukowych. Interpretowane razem prowadzą do stworzenia kompleksowej, połączonej i drożnej sieci instytucji edukacji, wychowania i opieki najmłodszych we wczesnym dzieciństwie. W sieci tej istnieje ścisły związek pomiędzy opieką zdrowotną, edukacją i usługami socjalnymi zarówno w wymiarze jednostkowym, jak i z uwzględnieniem konkretnych grup dzieci i ich rodzin (rys. 2). Podejście takie wymaga jednak zauważenia zmian w krajobrazie oferty instytucjonalnej oraz dopasowania jej do potrzeb społecznych (Wustmann, Simoni 2016: 24).

\section{Uniwersalna kompleksowa prewencja}

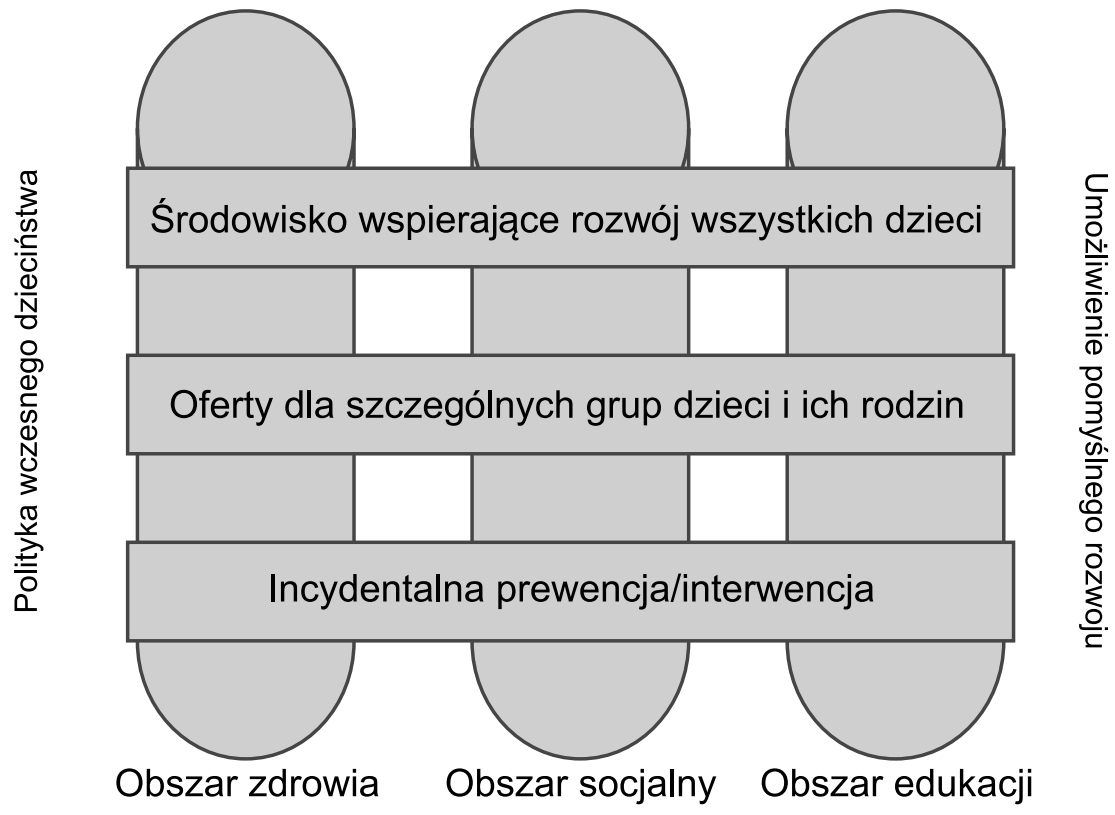

Szczególne środki ochrony dzieci

Rysunek 2. Zintegrowane ujęcie wczesnej edukacji, opieki i wychowania

Źródło: opracowanie własne na podstawie: Jacobs Foundation (2012). 
Zintegrowane podejście do wczesnej edukacji, opieki i wychowania przedstawione zostało w modelu Primokiz (por. rys. 2). Przez politykę wczesnego dzieciństwa rozumie się działania zapewniające każdemu dziecku porównywalne warunki rozwoju oraz, na ile to możliwe, wspieranie wszystkich dzieci w ich rozwoju. Jest to interpretowane jako wspólne zadanie systemów: edukacyjnego, zdrowotnego i socjalnego. Tworzą one filary wspierające holistyczną/zintegrowaną edukację, opiekę i wychowanie we wczesnym dzieciństwie. Model zakłada również, że polityka wczesnego dzieciństwa obejmuje zarówno otoczenie rodzinne, jak i instytucjonalne, zorientowane na zapewnienie dzieciom warunków odpowiadających wszystkim dzieciom i każdemu z osobna. Usługi oparte na zaspokajaniu potrzeb wszystkich dzieci i ich rodziców, szczególnych potrzeb niektórych dzieci i ich rodziców, a także usługi skierowane do poszczególnych dzieci i ich rodzin mogą być oferowane właśnie w tym modelu. Polityka wczesnego dzieciństwa, jako zintegrowane podejście, tworzy spoiwo łączące poszczególne obszary na różnych poziomach modelu.

Skupienie się na spójności pionowej i poziomej eksponuje koordynację usług i ich struktur dla dzieci w określonej grupie wiekowej oraz projektowanie przejścia od narodzin do wejścia do szkoły. Autorzy modelu zwracają uwagę na to, że polityka wczesnego dzieciństwa koncentruje się również na wielu innych ofertach i formach instytucjonalnych, które zajmują się wsparciem dziecka w jego rozwoju, jak czyni to pomoc społeczna czy szkolnictwo.

\section{Podsumowanie}

Można przyjąć, że debaty i dyskusje polityczno-oświatowe po roku 2000 zostały zdominowane - jak to określano - przez „,nowe, magiczne określenie: frühkindliche Bildung”, w dosłownym tłumaczeniu wczesnodziecięcą edukację (Franke-Meyer 2016). Rezultaty badań PISA, według których osiągnięcia niemieckich uczniów znajdowały się poniżej średniej OECD, przebudziły społeczeństwo Niemiec i zwróciły uwagę na rangę edukacji $\mathrm{i}$ instytucji przedszkolnych.

Niemcy w porównaniu z innymi krajami europejskimi wykazują na tym polu duże zaległości i zapotrzebowanie na radykalne przeobrażenia przedszkoli. Jednakże tempo i sposób podejścia do kwestii zarówno pedagogicznych (koncepcyjnych), jak i organizacyjnych zależy od decyzji politycznych oraz ustaleń formalno-prawnych. Dotyczy to wielu kwestii: jakości wyposażenia, dalszej rozbudowy ofert, miejsc dla dzieci, czasu opieki, a także specjalistycznego kształcenia personelu pedagogicznego. Innym poważnym wyzwaniem jest radzenie sobie z heterogenicznością (Umgang mit Heterogenität), dużą różnorodnością grup i zagadnieniami związanymi z inkluzją. Również kwestie pedagogiki żłobkowej stanowią obecnie wyzwanie stojące przed instytucjami dla małych dzieci.

Intensywność podejmowanych w Niemczech działań oraz zasięg toczących się debat na temat wczesnego dzieciństwa to zjawiska, które nigdy wcześniej nie występowały w tak dużej skali, nie angażowały tak wielu grup społecznych. Co ważne, mobilizują one siły 
polityczne gotowe do wprowadzenia i finansowania zmian. W debatach na temat reform edukacyjnych wróciła także kwestia dużego zapotrzebowania na połączenie oddziaływań przedszkola i szkoły w jeden spójny model. W rezolucji Konferencji Ministrów ds. Młodzieży z 2002 r. podkreślono wymóg intensywnej współpracy między placówkami przedszkolnymi a szkołami podstawowymi. W rezultacie podkreślono konieczność wzajemnej wymiany doświadczeń oraz precyzji w formułowaniu wymagań i oczekiwań przedszkola. Zalecenia współpracy mają się także przyczynić do usprawnienia pracy szkoły i poprawy jakości edukacji dzięki lepszemu wykorzystaniu procesów edukacyjnych realizowanych w przedszkolach (Jugendministerkonferenz 2002).

Istotne na nowo stało się wyjaśnienie, w jaki sposób można przygotowywać dzieci do szkoły oraz jak szkoła może wykorzystywać doświadczenia dzieci zdobyte w przedszkolu. Powrócono do zapomnianej nieco misji przedszkoli przygotowania dzieci do edukacji szkolnej (Reyer 2006), która jednak nie znalazła się w zapisach ustawy o opiece nad dziećmi i młodzieżą. Inaczej jest w przepisach ustanawianych na poziomie krajów związkowych. Często wykazuje się, że przedszkole ma własną misję edukacyjną. Diana Franke-Meyer zwraca uwagę, że przedszkole w pewnym stopniu oddzieliło się od szkoły. „W trakcie bieżących debat reformatorskich, w których procesy edukacyjne przedszkola mają być powiązane z procesami szkolnymi, przestrzeganie sformułowania niezależnego mandatu edukacyjnego wydaje się dziwne. $Z$ jednej strony przedszkole ma nawiązywać owocne kontakty ze szkołą, a z drugiej wyróżniać się niezależnością. Powstała w ten sposób sprzeczność wymaga odpowiedzi na pytanie: jak zaprojektować wczesną edukację bez konieczności oddzielania jej od szkoły" (Franke-Meyer 2011: 6). Można się spodziewać, że na pytania te najbliższym czasie nie otrzymamy odpowiedzi.

\section{Literatura}

Bundesministerium für Familie, Senioren, Frauen und Jugend (BMFSFJ)/ Jugend- und Familienministerkonferenz (JFMK) (Hrsg.) (2016), Frühe Bildung weiterentwickeln und finanziell sichern. Zwischenbericht 2016 von Bund und Ländern und Erklärung der Bund-Länder-Konferenz.

DGfE (2005), Stellungnahme zur Qualifizierung des Personals im Bereich der ,Vorschulischen Pädagogik”. „Vorstand der Deutsche Gesellschaft für Erziehungswissenschaft”, 16.07.2005. http:// www.dgfe.de/fileadmin/OrdnerRedak teure/Stellungnahmen/2005_07_Vorschulp\%C3\%A4dagogik.pdf, 25.10.2017.

EKFF (2008), Eidgenössische Koordinationskommission für Familienfragen (Hrsg.), Familien, Bildung, Erziehung. Bern.

EKFF (2009), Eidgenössische Koordinationskommission für Familienfragen (Hrsg.), Familien- und schulergänzende Kinderbetreuung. Eine Bestandesaufnahme der Eidgenössischen Koordinationskommission für Familienfragen EKFF. Bern.

EKM (2009), Eidgenössische Kommission für Migrationsfragen (Hrsg.), Frühförderung. Empfehlungen der Eidgenössischen Kommission für Migrationsfragen EKM.

Erning G. (1987), Geschichte der öffentlichen Kleinkinderziehung von den Anfängen bis zum Kaiserreich. W: G. Erning, K. Neumann, J. Reyer (Hrsg.), Geschichte des Kindergartens. Bd. 1: 
Entstehung und Entwicklung der öffentlichen Kleinkinderziehung in Deutschland von den Anfängen bis zur Gegenwart. Freiburg im Breisgau, Lambertus.

EU-Arbeitsgruppe für Frühkindliche Bildung und Betreuung unter der Schirmherrschaft der Europäischen Kommission (Hrsg.) (2014), Vorschlag für die Leitlinien eines Qualitätsrahmens für die Frühkindliche Bildung, Betreuung und Erziehung. Bericht der Arbeitsgruppe für Frühkindliche Bildung und Betreuung unter der Schirmherrschaft der Europäischen Kommission. https:// www.dji.de/fileadmin/user_upload/icec/ecec-quality-framework_de.pdf, 10.10.2019.

Eurydice-Netz (2009), Frühkindliche Betreuung, Bildung und Erziehung in Europa: ein Mittel zur Verringerung sozialer und kultureller Ungleichheiten. Brüssel, Europäische Union.

Eurydice Report (2019), Key Data on Early Childhood Education and Care in Europe 2019 Edition. Brussels, Education, Audiovisual and Culture Executive Agency, https://eurydice.org.pl/ wp-content/uploads/2019/07/KD_ECEC_2019_Report_EN.pdf, 10.10.2019.

Franke-Meyer D. (2011), Kleinkindererziehung und Kindergarten im historischen Prozess. Ihre Rolle im Spannungsfeld zwischen Bildungspolitik, Familie und Schule. Bad Heilbrunn, Klinkhardt.

Franke-Meyer D. (2016), Geschichte der frühkindlichen Bildung in Deutschland. https://www.bpb. de/gesellschaft/bildung/zukunft-bildung/239356/fruehkindliche-bildung, 25.06.2019.

Harsch H. (2008), Zur Geschichte früher außerfamiliärer Betreuung. „Psyche” 62(2).

Jacobs Foundation (2012), Program Primokiz. http://jacobsfoundation.org/de/project/primokiz-2/, 10.03.2018.

Jugendministerkonferenz (2002), TOP 4, Bildung fängt im frühen Kindesalter an. Beschluss vom 6/7 Juni 2002, www.jfmk.de, 5.06.2019.

Koller H.-Ch. (2012), Bildung anders denken. Einführung in die Theorie transformatorischer Bildungsprozesse. Stuttgart, Kohlhammer.

Komisja Europejska//EACEA/Eurydice (2014), Kluczowe dane dotyczace wczesnej edukacji i opieki w Europie. Raport Eurydice i Eurostatu Wydanie 2014. Warszawa, Fundacja Rozwoju Systemu Edukacji, https://eurydice.org.pl/wp-content/uploads/2015/03/PL_KD_ECEC2014.pdf, 10.07.2019.

Lazzari A. (2017), The current state of national ECEC quality frameworks, or equivalent strategic policy documents, governing ECEC quality in EU Member States. NESET II Ad Hoc Bericht $\mathrm{Nr}$ 4, http://nesetweb.eu/wp-content/uploads/AHQ4.pdf, 5.03.2018.

LifExperienceGmbHgemein (2019), Gemeinnützige Gesellschaft für Bildung, Erziehung und Betreung $\mathrm{mbH}$, Träger Leitbild. https://www.lifexperience.de/index.php/traeger-leitbild.html, 20.05.2019.

OECD (2001), Starting Strong I: Early childhood education and care. Paris, Organisation for Economic Co-operation and Development.

OECD (2006), Starting Strong II: Early childhood education and care. Paris, Organisation for Economic Co-operation and Development.

OECD (2013), Starting Strong III. Eine Qualitäts-Toolbox für die frühkindliche Bildung, Betreuung und Erziehung. München, DJI.

Pabst Ch., Schoyerer G. (2015), Wie entwickelt sich die Kindertagespflege in Deutschland? Weinheim Basel, Beltz Verlag.

Reyer J. (2006), Einführung in die Geschichte des Kindergartens und der Grundschule. Bad Heilbrunn, Klinkhardt-Verlag.

Schlussfolgerungen des Vorsitzes Europäischer Rat (Barcelona) 15. und 16. März 2002. https:// europa.eu/rapid/press-release_PRES-02-930_de.htm, 20.06.2019. 
Stasik E. (2019), Niemiecka prasa: Walkę z ubóstwem wygra się w przedszkolach $i$ szkołach, https://www.dw.com/pl/niemiecka-prasa-walk\%C4\%99-z-ub\%C3\%B3stwem-dzieci-wygrasi\%C4\%99-w-przedszkolach-i-szko\%C5\%82ach/a-47018360, 1.10.2019.

UNICEF (2008), The child care transition. A league table of early childhood education and care in economically advanced countries. Florence, UNICEF Innocenti Research Centre.

Wustmann S.C., Simoni H. (2016), Orientierungsrahmen für frühkindliche Bildung, Betreuung und Erziehung in der Schweiz. Zürich, Erarbeitet vom Marie Meierhofer Institut für das Kind, im Auftrag der Schweizerischen UNESCO-Kommission und des Netzwerks Kinderbetreuung Schweiz. 